\title{
TWAIL'S OTHERS: A CASTE CRITIQUE OF TWAILERS AND THEIR FIELD OF ANALYSIS
}

\author{
Srinivas Burra*
}

Third World Approaches to International Law [TWAIL] constitutes a significant method of analysis of contemporary international law. TWAIL as a methodological framework continues the tradition of critical scholarship in international law. Arguably it can be considered as a major methodological framework emerged in international law after the end of the cold war. Unlike some other critical traditions of international law scholarship, TWAIL claims to accommodate varying conceptual standpoints to reflect on international law critically. This feature of TWAIL scholarship seems to reflect the prevailing suspicion of conceptual metanarratives at the time when TWAIL as a methodological framework was emerging. A noteworthy feature of the TWAIL framework is that it broadly defines its field of analysis by claiming to represent the concerns of the global south. However, a dispassionate interrogation arguably reveals that TWAIL, despite coming as a response to the colonialist and post-colonial hegemonic frameworks of international law, does not seem to capture the concerns of all the margins. In other words, TWAIL does not seem to reflect the multitude of mainstream international law's others in terms of their subjective participation in knowledge production as well as in terms of their lived experiences becoming subjects of analysis. An example of this in the South Asian context is the marginalization of peoples of lower castes and indigenous peoples, who are historically kept away from knowledge production and whose lived experiences only recently received the attention as subjects of serious analysis. TWAIL scholarship does not seem to reflect this glaring reality. An attempt is made to analyze the probable reasons behind this exclusion, looking at the social being of the TWAIL intellectual, and to emphasize on the need of the organic TWAIL intellectual.

Le mouvement Third World Approaches to International Law (TWAIL) constitue une importante méthode d'analyse du droit international contemporain. En tant que cadre méthodologique, TWAIL poursuit la tradition de la recherche universitaire critique en droit international. On peut considérer TWAIL comme un cadre méthodologique majeur qui a vu le jour dans le droit international après la fin de la guerre froide. Contrairement à certaines autres traditions critiques de la recherche universitaire. TWAIL prétend concilier des points de vue conceptuels variés pour avoir une réflexion critique sur le

Assistant Professor, Faculty of Legal Studies, South Asian University, New Delhi; srinivasb@sau.ac.in. I thank the organizers of the "Third World Approaches to International Law Conference: On Praxis and the Intellectual" held at the American University in Cairo from 21 to 24 February 2015 and the "Third World Approaches to International Law Workshop: On Praxis and the Intellectual" held at the University of Windsor, Ontario, Canada from 6-8 June 2015, where I presented the earlier drafts of this paper. Comments from the participants of both the events helped me immensely in finalizing the paper. I also thank the anonymous reviewers for their valuable comments. All errors are mine. 
droit international. Cette caractéristique de la mission de recherche de TWAIL semble cristalliser le soupçon prédominant de l'existence de métadiscours conceptuels à l'époque où TWAIL émergeait en tant que cadre méthodologique. Une des particularités dignes de mention du cadre de TWAIL est qu'il définit son champ d'analyse en affirmant représenter les préoccupations du Sud. Toutefois, un questionnement dépassionné révèle peut-être que bien que TWAIL soit une réponse aux cadres hégémoniques colonialistes et postcoloniaux $d u$ droit international, ce mouvement ne semble pas englober les préoccupations de tous les courants marginaux. Autrement dit, TWAIL ne semble pas être le reflet de la multitude d'autres acteurs habituels du droit international en ce qui concerne leur participation subjective à la production de connaissances comme en ce qui concerne la transformation de leur expérience vécue en sujets d'analyse. On peut citer comme exemple, pour l'Asie du Sud, la marginalisation des peuples des castes inférieures et des peuples indigènes, qui sont depuis toujours tenus à l'écart de la production de connaissances et dont on s'intéresse à l'expérience vécue comme sujet d'analyse sérieuse depuis peu. La mission de recherche de TWAIL ne semble pas prendre en compte cette flagrante réalité. On tente ici d'analyser les raisons probables de cette exclusion en se penchant sur l'être social de l'intellectuel TWAIL et de mettre l'accent sur la nécessité de l'intellectuel organique TWAIL.

\section{INTRODUCTION}

Third World Approaches to International Law [TWAIL] as a methodological framework continues the tradition of critical scholarship in international law. Arguably, it can be considered as a major methodological framework that emerged in international law after the collapse of the erstwhile Soviet Union and the end of the cold war. ${ }^{1}$ Unlike some other critical traditions of international law scholarship TWAIL claims to accommodate varying conceptual standpoints that engage with international law critically. This feature seems to reflect the prevailing suspicion of conceptual metanarratives at the time when TWAIL as a methodological framework was emerging. ${ }^{2}$ Thus it affirms to constitute scholars claiming to subscribe to different conceptual standpoints. This diversity of conceptual standpoints of the TWAIL scholars seems to be a conscious choice as opposed to overarching methodological frameworks. As its 1997 vision statement underlines, there is not necessarily an agreement among TWAILers on all issues of the TWAIL. The Statement says:

Members of this network may not agree on the content, direction and strategies of third world approaches to international law. Our network, however, is grounded in the united recognition that we need democratization of international legal scholarship in at least two

\footnotetext{
1 This is considering the fact that the first formal TWAIL group was initiated at the New Approaches to Third World Legal Studies Conference on March 8-9 of 1997 at Harvard Law School. However, there is a general understanding among TWAIL scholars that third world critique started prominently during the period of decolonization.

2 This is particularly the case that with the disintegration of the erstwhile Soviet Union the emancipatory potential of Marxism as an overarching theoretical project was put to question mainly in academia.
} 
senses: (i) first, we need to contest international law's privileging of European and North American voices by providing institutional and imaginative opportunities for participation from the third world; and (ii) second, we need to formulate a substantive critique of the politics and scholarship of mainstream international law to the extent that it has helped reproduce structures that marginalize and dominate third world peoples. ${ }^{3}$

It does not mean that there is no agreement at all on any issues since it clearly identifies its intellectual goals, i.e., democratize the international legal scholarship by facilitating participation from the third world and critique the marginalization and domination experienced by third world peoples. Thus it essentially indicts the global north for the subjugation of the global south through colonial encounter and continuation of similar domination in the post-colonial and contemporary world. A large portion of scholarly work that has emerged since the first TWAIL conference arguably may fall under the scope of these two agenda items. This paper attempts to evaluate TWAIL as an intellectual movement in the background of its stated aims, as broadly can be captured in the above stated vision statement. For that purpose, the paper attempts to analyze the TWAIL scholarship and contextualize the TWAIL scholar who produces it within the backdrop of the vision statement which aims to "contest international law's privileging of European and North American voices". ${ }^{4}$ It engages with the third world international lawyer as producer of scholarship with a suspicion of her/his credentials as anti-hierarchical and counter hegemonic in relation to certain forms of marginalization and domination. ${ }^{5}$ The aim is to investigate the emancipatory potential of the scholarship produced by the 'abstract' third world international lawyer. It is not to doubt the emancipatory potential of the scholarship of the third world international lawyer in every respect. The attempt is to investigate the following. In the process of producing emancipatory legal discourse, is the third world international lawyer relegating certain concrete oppressed voices? Also in the process relegating the emancipatory discourse of those concrete oppressed voices?

It can be elicited from the writings that, while emphasizing the third world international lawyer and her/his scholarship, TWAIL is generalized as a progressive narrative. It is argued here that this narrative is contestable in certain contexts. This critical dimension of contestability in certain contexts highlights some fundamental conceptual problems of the TWAIL project which will be dealt with at the end of this paper. Thus the attempt in this paper is to show that while emphasizing the dominance of European and North American voices and the scholarship, certain third world voices and issues are pushed into oblivion. Non recognition of these third world voices and issues leads to the suspicion of emancipatory potential of the TWAIL scholarship despite its well-intentioned challenge to the European and North American voices. To substantiate its theme of critiquing the TWAIL scholarship, the paper attempts to look at the TWAIL scholarship emerged from India and produced by Indian international lawyers as TWAILers. This is analyzed in the context of Indian social reality based on the hierarchical caste

3 Cited in Karin Mickelson, "Taking Stock of TWAIL Histories" (2008) 10 Intl Community L Rev at 357-358. This statement is taken as a relatively formal articulation of the TWAIL vision, while being aware that some writings produced under the umbrella of TWAIL scholarship might not fit into these theoretical boundaries.

4 Ibid

5 To use Makau Mutua's formulation of TWAIL as antihierarchical, counter hegemonic, suspicious of universal creeds and truths and is a conciliatory movement, Makau Mutua, "What is TWAIL?" (2000) 94 Proceedings of the Annual Meeting (Am Soc of Intl L) 31 . 
system. While underlining the discriminatory nature of caste system in general and its impact on the process of knowledge production in India, an attempt is made here to point out that the TWAIL scholarship from India so far failed to take cognizance of this discriminatory social reality in its scholarship.

Before dealing with the main theme, the paper contextualizes the caste discrimination in the international law debates to establish that the caste question has not been adequately addressed for too long by the international law treaties and institutional mechanisms. In the last two decades there have been efforts to deal with the issue at international law forums, however, inadequately. This inadequacy is pointed out to underline that TWAIL scholarship failed to articulate it in its critical scholarship.

Part Two of this paper briefly explains the system of caste in India and its discriminatory effect on the Indian social reality. Part Three deals with the problem of caste discrimination in the context of international human rights law and debates surrounding the Durban Conference against Racism Racial Discrimination, Xenophobia and Related Intolerance. Part Four focuses on Indian international lawyers with a particular emphasis on TWAIL scholars from India and their scholarship, specifically in relation to the question of caste discrimination. Part Five deals with TWAIL scholarship's conceptual premises and caste discrimination. Part Six provides a conclusion.

\section{CASTE SYSTEM IN INDIA ${ }^{6}$}

Any serious attempt to understand Indian social reality in both an historical and a contemporary sense inevitably leads one to confront the caste system in its manifold forms. The caste system operates in the form of division of society into different castes which are placed hierarchically and are endogamous groups. A person who is born into a particular caste remains in the same caste. Hindu society is divided into Varnas and it is understood that castes have evolved from Varnas. According to Hindu texts there are four Varnas, otherwise known as the chaturvarna system. The four Varnas are 'Brahmins' which consists of priestly castes, 'Kshatriyas' are the warrior castes, 'Vaishyas' are the trading castes, and lastly 'Shudras' are the working castes like artisans, cleaners, food gatherers, hunters and potters. There is fifth category of people who are not part of the four varnas, previously known as untouchables or outcastes, and are often referred to as Dalits ${ }^{7}$ in contemporary India. People belonging to this fifth group were treated as untouchables and were assigned menial jobs like butchery, manual scavenging, making of footwear and dealing with animal carcasses. Of the five groups Brahmins are at the top of the hierarchy and are assigned with intellectual tasks. The Hindu text to which the classification of the Varna system is attributed is the Purushasuktha of Rigveda. ${ }^{8}$ According to Purushasuktha four Varnas emerge from Purusha. Brahmins emerged from his mouth, Kshatriyas from his arms, Vaishyas from his thighs and

6 This section is intended only to highlight the discriminatory elements of the caste system which are relevant to the following sections, therefore, it does not deal with it comprehensively.

7 'Dalit' means 'crushed' or 'broken' in Marathi, an Indian language. The word was coined by Jotirao Phule (1827-1890). See, Anand Teltumbde, The Persistence of Caste: The Khairlanji Murders and India's Hidden Apartheid (Delhi: Navayana, 2014).

8 Ibid at 12. For the genesis of the caste system in India, also see, BR Ambedkar, "Castes in India: Their Mechanism, Genesis, and Development”, in Sharmila Rege, ed, Against the Madness of Manu (New Delhi: Navayana, 2013) at 77107. 
Shudras from his feet. Unlike other social identities such as class, religion, nationality and citizenship, caste identity cannot be changed within the Hindu fold, and movement from one caste to the other is restricted. ${ }^{9}$ The caste gradation was codified in the form of laws of Manu in Manusmriti which is said to have been composed around second century CE. ${ }^{10}$ It is possible that the caste system may be misunderstood as division of labour which takes place in every society in some form or the other. B. R. Ambedkar aptly counters this understanding and asserts that the caste system is not merely division of labour but, it is also division of labourers. ${ }^{11}$

As each caste group is entrusted with designated labour, intellectual labour is largely confined to certain castes which stand at the top of the caste hierarchy. This classification continues to be part of the Indian social reality despite the legislative and administrative measures in the post-independence India against certain caste related practices, especially untouchability. ${ }^{12}$ It is an established fact that people belonging to lower castes are barely represented in the institutionalized and formal knowledge production, particularly in places like academia. There have been constitutional measures to address this issue like affirmative action known as reservations. As a result of this centuries-old discrimination, the lower caste people are kept out of some of the professions, mainly from those which are considered as intellectual activities and therefore graded as superior to other forms of labour. Their absence is so apparent even now that they hardly exceed the reserved quotas in the academic and other government jobs.

\section{CASTE DISCRIMINATION AND INTERNATIONAL HUMAN RIGHTS DISCOURSES}

The expanding scope of human rights at the international level over the last sixty years has been phenomenal both in terms of quality and quantity. It is not an exaggeration to say that almost every perceivable human activity and human relationship are sought to be defined in the language of rights. The legitimacy of this human rights discourse continues to force States to make an apparent distinction between human rights obligations and other obligations under international law as the defense of State sovereignty has become relatively unsustainable in the case of the former. This is not to suggest that States unfailingly comply with their international human rights obligations in domestic affairs, but to underscore the moral superiority of human rights language in international relations. The overarching

9 However, Anand Teltumbde holds the view that "[t]he commonplace understanding of the caste system as having held Indian society in fossilized form for over two millennia is therefore not quite correct. While it is accurate so far as the broad varna framework is concerned, the castes within this framework have been fluid. Many new castes were formed and many have disappeared; many split up and many merged with others over time in response to local political and economic demands". Teltumbde, supra note 7 at 15.

10 BR Ambedkar, Annihilation of Caste: The Annotated Critical edition (New Delhi: Navayana, 2014), see the text of note 97 at 269 [Ambedkar, Annhilation of Caste].

11 Ambedkar says: "Civilised society undoubtedly needs division of labour. But in no civilised society is division of labour accompanied by this unnatural division of labourers into watertight compartments. The caste system is not merely a division of labourers - which is quite different from division of labour - it is a hierarchy in which the division of labourers are graded one above the other. In no other country is the division of labour accompanied by this gradation of labourers". Ibid at 233-234.

12 See Smitha Narula, "Equal by Law, Unequal by Caste: The 'Untouchable' Condition in Critical Race Perspective" (2008) 26 Wis Intl LJ 255. 
scope of human rights includes instruments dealing with a general framework of rights, like the civil and political rights and economic, social and cultural rights and also instruments dealing with specific aspects like race, gender, child rights and disability. ${ }^{13}$ However, there is a conspicuous absence of any reference to caste discrimination in any of these instruments. Caste discrimination, which is predominantly prevalent in South Asia, particularly in India, deserves similar, if not more attention if the number of people affected by this phenomenon and gravity of the problem are the constituting factors for an issue to be given attention under the rubric of international human rights law. It is estimated that more than 260 million people are affected by the caste discrimination. ${ }^{14}$ As the caste system is hierarchical and those castes which are at the bottom of the hierarchy are the worst sufferers, the graded nature of the caste would affect many other middle and lower castes too. Then the number of people affected in different forms can be much higher.

However, so far it received inadequate attention at the international level including in international law debates. While trying to understand the reasons for the absence of caste related debates at the international level, Arundhati Roy says that:

"[o]ther contemporary abominations like apartheid, racism, sexism, economic imperialism and religious fundamentalism have been politically and intellectually challenged at international forums. How is it that the practice of caste in India-one of the most brutal modes of hierarchical social organisation that human society has known- has managed to escape similar scrutiny and censure? Perhaps because it has come to be so fused with Hinduism, and by extension with so much that is seen to be kind and goodmysticism, spiritualism, non-violence, tolerance, vegetarianism, Gandhi, yoga, backpackers, the Beatles-that, at least to outsiders, it seems impossible to pry it loose and try to understand it". 15

Having existed for so long and not adequately addressed by the international community, the institution of caste system has been the subject of fierce debates resulting in certain constitutional, policy and legal safeguards at the domestic level of various South Asian countries, particularly in India. ${ }^{16}$ However, it has been found that these laws fail to address the caste discrimination in its totality. ${ }^{17}$ Its continuing marginalization from the international discourses partially ended with the Durban World Conference

13 For detailed information about international human rights law, especially under the United Nations system, see, United Nations Human Rights: Office of the High Commissioner, online: $<$ http://www.ohchr.org $>$.

14 Though the problem of caste discrimination is predominant in South Asia, in a few other countries similar discrimination exists. According to UN treaty bodies' references to the caste discrimination, 19 countries are affected by it. These are: India, Nepal, Pakistan, Bangladesh, Japan, United Kingdom, Yemen, Sri Lanka, Nigeria, Mauritania, Madagascar, Senegal, Chad, Mali, Ethiopia, Ghana, Burkina Faso, Mauritius and Micronesia.

15 Arundhati Roy, "The Doctor and the Saint", in Ambedkar, Annhilation of Caste, supra note 10 at 22.

16 The Constitution of India (1950) provides for the positive discrimination for the lower caste people through reservations in the areas of government employment and higher education (Articles 15(4) and (16(4)). Article 17 of the Constitution also abolishes untouchability and its practice in any form is forbidden. Other important legislation include: Protection of Civil Rights Act, 1955, and the Scheduled Caste and Scheduled Tribe (Prevention of Atrocities) Act, 1989.

17 William J. Eisenman, "Eliminating Discriminatory Traditions against Dalits: The Local Need for International CapacityBuilding of the Indian Criminal Justice System” (2003) 17 Emory Intl L Rev 133. 
against Racism in $2001^{18}$, where interested groups, mainly from India fervently fought for it to be put on to the agenda of the international community. While recognizing the significance of recent debates at the international level on the issue of caste discrimination, what needs to be emphasized is the indifference of the discourses on international law, particularly human rights law, which ultimately forced the victim and activist groups to campaign for the inclusion of the issue on the mainstream agenda of the international community. Thus, the issue attained required publicity and scholarly consideration for its inclusion at the World Conference against Racism.

\section{A. Pre Durban Developments}

As pointed out earlier there has been a considerable development of international human rights law after the establishment of the United Nations. India has been actively participating in these developments and has become a party to some of the important human rights treaties. ${ }^{19}$ However, the question of caste discrimination never drew any serious attention in any of the forums dealing with human rights issues till 1996, when it received the attention of the Committee on the Elimination of Racial Discrimination [CERD] in a substantive way. ${ }^{20}$ In its periodic report submitted to the CERD in 1996, the government of India stated its position on caste discrimination in the context of the racial discrimination Convention. India's periodic report stated:

Article 1 of the Convention includes in the definition of racial discrimination the term "descent". Both castes and tribes are systems based on "descent" since people are normally born into a particular caste or a particular tribe. It is obvious, however, that the use of the term "descent" in the Convention clearly refers to "race". Communities which fall under the definition of Scheduled Castes and Scheduled Tribes are unique to Indian society and its historical process. As conveyed to the Committee during the presentation of India's last periodic report, it is, therefore, submitted that the policies of the Indian Government relating to Scheduled Castes and Scheduled Tribes do not come under the purview of Article 1 of the Convention. As a matter of courtesy to the members of the Committee, the Government is, however, happy to provide any information that they may require on this subject. ${ }^{21}$

18 World Conference against Racism, Racial Discrimination, Xenophobia and Related Intolerance was held in Durban, South Africa, from 31 August to 8 September 2001.

19 India is a party to six out of the nine core human rights treaties. These are: International Convention on the Elimination of All Forms of Racial Discrimination (ICERD), International Covenant on Civil and Political Rights (ICCPR), International Covenant on Economic, Social and Cultural Rights (ICESCR), Convention on the Elimination of All forms of Discrimination against Women (CEDAW), Convention on the Rights of the Child (CRC), and Convention on the Rights of Persons with Disabilities (CRPD).

20 The Committee on the Elimination of Racial Discrimination (CERD) is the body of independent experts that monitors implementation of the Convention on the Elimination of All Forms of Racial Discrimination by its State parties. This Convention was adopted on 21 December 1965 and entered into force on 4 January 1969. India became a party to the Convention in 1968.

21 CERD/C/299/Add.3, paragraph 7. 
In response to this view the CERD stated that "the term "descent" mentioned in Article 1 of the Convention does not solely refer to race. The Committee affirms that the situation of the scheduled castes and scheduled tribes falls within the scope of the Convention". ${ }^{22}$ The Committee further stated that:

although constitutional provisions and legal texts exist to abolish untouchability and to protect the members of scheduled castes and scheduled tribes, and although social and educational policies have been adopted to improve the situation of members of scheduled castes and scheduled tribes and to protect them from abuses, widespread discrimination against them and relative impunity of those who abuse them point to the limited effect of these measures. The Committee is particularly concerned at reports that people belonging to the scheduled castes and scheduled tribes are often prevented from using public wells or from entering cafes or restaurants and that their children are sometimes separated from other children in schools, in violation of Article 5 (f) of the Convention. ${ }^{23}$

\section{B. Durban and post Durban Developments}

World Conference against Racism, Racial Discrimination, Xenophobia and related Intolerance [WCAR] was held in Durban in 2001. Prior to this conference, preparatory ("PrepCom") meetings were also held. Before these PrepCom meetings, the International Human Rights Law Group organized a consultation on the WCAR at Bellagio, which recommended that caste discrimination against Dalits should be part of the agenda of the PrepCom meetings and also WCAR ${ }^{24}$ At the first World Conference PrepCom meeting in Geneva in May 2000 it was suggested that the 'caste' and 'Dalit' discrimination should be included on the agenda of the WCAR. Another PrepCom meeting for the Asia-Pacific region was held in Tehran in February 2001 wherein the Government of Nepal made a statement admitting the problem of caste discrimination against Dalits and declared that the issue should be addressed at the WCAR. $^{25}$

As pointed out earlier, no reference to caste discrimination is found in any of the international human rights instruments. The rallying point of the NGO groups at the Durban conference was to equate caste discrimination with racial discrimination under the category of descent based discrimination. Dalit groups mainly from India, Nepal and Buraku people from Japan argued for the recognition of discrimination based on caste and social origin or include these forms of discrimination within the scope of descent based discrimination. ${ }^{26}$

The government of India's response in this context was:

CERD Concluding Observations-India 1996, CERD/C/304/Add. 13 at para 14.

Ibid at para 23.

24 See International Human Rights Law Group, "Bellagio Consultation on the UN World Conference against Racism", January 2000, online <http://www.hrlawgroup.org/resources/content/BellagioEnglish.pdf $>$

25 Sukhadeo Thorat \& Umakant, "Introduction" in Sukhadeo Thorat and Umakant, eds, Caste, Race and Discrimination: Discourses in International Context (New Delhi: Indian Institute of Dalit Studies, 2013) at xxi.

26 Ibid at xxii-xxiii. 
We are firmly of the view that the issue of caste is not an appropriate subject for discussion at this Conference... It is neither legitimate nor feasible nor practical for this World Conference or, for that matter, even the UN to legislate, let alone police, individual behaviour in our societies. The battle has to be fought within our respective societies to change thoughts, processes and attitudes; indeed, the hearts and souls of our peoples. ${ }^{27}$

The Indian government continued to subscribe to the view that caste did not fall under the category of racial discrimination and therefore they could not be equated with each other. In its periodic report submitted to the CERD in 2006 it reiterated its position and held that "'caste' cannot be equated with 'race' or covered under 'descent' under Article 1 of the Convention". ${ }^{28}$

India's position on caste discrimination seems to be different from what it was in the past. When the Universal Declaration of Human Rights [UDHR] was being drafted, India wanted to include caste as one of the prohibited grounds of discrimination. When there was a discussion on the inclusion of 'birth' as one of the prohibited grounds of discrimination, the Indian representative favoured the inclusion of caste as one of the prohibited grounds instead of birth. Later, the Indian representative did not insist on the proposal, arguing that the words 'other status' and 'social origin' were broad enough to cover other forms of discrimination ${ }^{29}$ Similarly the word 'descent' was not used in any of the human rights and antidiscrimination related instruments prior to the racial discrimination Convention. ${ }^{30}$ It was also not part of the draft of the racial discrimination Convention taken for discussion. However, it was included in an

27 Statement by Mr. Omar Abdullah, Minister of State for External Affairs, Government of India delivered at the World Conference Against Racism, Racial Discrimination, Xenophobia and Related Violence, Durban South Africa, 2

September 2000, online: United Nations <http://www.un.org/WCAR/statements/indiaE.htm>.

28 The periodic report further states:

It may be recalled that in the last periodic report it was submitted that the Constitution of India prohibits discrimination on the basis of race. This was done by the framers of the Indian constitution drawing upon the provisions of the United States Constitution and the Charter of the United Nations while drafting the chapter on the fundamental rights. The other major factors which influenced the inclusion of specific reference to race was the rampant racial discrimination experienced in India during the colonial rule and moral outrage of the world community against racism in the immediate aftermath of the Second World War. Also 'race' and 'caste' are mentioned separately in the Indian Constitution as prohibited grounds of discrimination. Therefore they cannot be considered to be interchangeable or synonymous. If the concept of caste was included in race, there was no reason to mention them separately. Therefore, as in the last Report, information pertaining to Scheduled Castes and Scheduled Tribes or issues related to this group has not been provided in the present Report. As a matter of courtesy to the members of the Committee, if it so desires, the Government of India would be happy to provide information relating to Scheduled Castes and Scheduled Tribes to them though not as a reporting obligation under CERD. CERD/C/IND/19, paras 16-17. 
amendment proposed by India and was accepted and incorporated into the Convention. ${ }^{31}$ These examples arguably show that India was not against including caste discrimination in the international human rights law corpus and was not against it being discussed at international fora in general. However, these examples seem to contradict the present position of the government of India on the question of contextualizing caste discrimination in the framework of international human rights law.

The Durban conference provided an historic opportunity for Dalit activist and support groups predominantly from India, supported by other groups undergoing similar discrimination in other countries from Asia, Africa and also from Europe. These groups succeeded in convincing some States to include a paragraph in the draft Programme of Action dealing with descent based discrimination. ${ }^{32}$ However, the government of India succeeded in removing it from the Final Programme of Action adopted by the Conference. Despite the unsuccessful attempt of non-governmental groups to include a reference to caste in the Final Programme of Action, the process of mobilization of public opinion at the Durban conference created scope for future action. It is to be looked at, particularly from a critical perspective, whether those who argued for the inclusion of caste in the race believed that once it was accepted, that it would make a positive dent to the system of caste? The answer may not be necessarily 'yes'. It can be reasonably expected that all those NGOs who were in the forefront were aware of the domestic legal mechanisms available against caste discrimination and also their failure so far in alleviating the plight of the lower caste people. Therefore they would not have expected much in terms of concrete results from the recognition of caste discrimination on par with racial discrimination at the international level. ${ }^{33}$ However, a resultant factor would have been to build solidarity across the regions with those similarly placed and forge alliances for bringing caste and other similar forms of discrimination into the framework of international human rights.

Other human rights bodies started recognizing the issue of caste discrimination more than earlier. An important development was that the CERD issued a General Recommendation in 2002 affirming that caste discrimination falls under the category of descent within Article1(1) of the Racial Discrimination

31 Egon Schwelb, "The International Convention on the Elimination of All Forms of Racial Discrimination" (1966) 15 ICLQ at 1002-1003. While pointing out that the records of the Convention do not provide any indication of the situations that 'descent' is intended to cover, Egon Schwelb holds that "[i]t is reasonable to assume that the term descent" includes the notion of "caste", which is a prohibited ground of discrimination in Indian Constitutional Law (Art 15 of the Constitution of India (1950)). However the Constitution also uses the expression "descent" side-by-side with "caste" (Art 16). A contrary view is taken by David Keane, who argues that, constituent Assembly debates of the Indian Constitution do not provide any clarity on what constitutes "descent" and it is clear from its use along with caste in article 16(2) of the Constitution that they are two different things. David Keane, "Descent based Discrimination in International Law: A Legal History" (2005) 11 Intl J Minority Group Rights at 93-116; David Keane, Caste-based Discrimination in International Human Rights Law (Aldershot: Ashgate, 2007).

32 The relevant paragraph, paragraph 73 of the draft Programme of Action read as follows: "Urges States to ensure that all necessary constitutional, legislative and administrative measures, including appropriate forms of affirmative action, are in place to prohibit and redress discrimination on the basis of work and descent, and that such measures are respected and implemented by all State authorities at all levels". [emphasis original]

33 Ambedkar himself was not in favour of equating caste with race. He said " $[\mathrm{t}] \mathrm{o}$ hold that distinctions of castes are really distinctions of race, and to treat different castes as though they were so many different races, is a gross perversion of facts..."

"The caste system does not demarcate racial division. The caste system is a social division of people of the same race." Ambedkar, Annihilation of Caste, supra note 10 at 237-238. 
Convention. ${ }^{34}$ Other human rights bodies made reference to caste discrimination on various occasions. For the period 1991-2015, 72 concluding observations were made by various treaty bodies. ${ }^{35}$ The Human Rights Council also issued a final report on the question of discrimination based on work and descent in 2009 which includes Draft Principles and Guidelines for the Effective Elimination of Discrimination Based on Work and Descent. ${ }^{36}$

Traditionally, international law-making is understood as the exclusive domain of States, while people in any form whatsoever are excluded from direct participation as States impersonate them by representing the collective consciousness of their respective peoples. It has been argued that this impermeable legislative monopoly of States has suffered a dent during the last two decades or so with the active mobilizational tactics of non-governmental organizations [NGOs] at the international level. While the impervious character of States remains intact, as it is they who attest to these instruments and implement them at the national level, the nongovernmental groups' activism has been successful in setting the agenda on certain issues and creating the required public opinion and pressure to compel States to adopt international instruments. ${ }^{37}$ This is similar to what occurred when a coalition of NGOs, which campaigned for inclusion of caste on the agenda of the Durban conference. The distinguishing feature of this mobilization of public opinion is that these NGOs have mostly acted as providers of the required public voice with the necessary appeal and articulation. The question that should arise in this context is, where did this campaign obtain its moral and ideological legitimacy to garner the support that it has achieved. The answer to this question lies in the fact that the NGOs' mobilization took place against the backdrop of the large-scale social movements against caste discrimination, particularly in India. This is not an apt place to trace the genealogy and elaborate the physiognomy of these anti-caste movements. What is relevant here is to underline the influence of social movements on international law. For the purpose of the present article it is significant to know how the international law scholarship,

34 General recommendation reads as follows:

Confirming the consistent view of the Committee that the term "descent" in article 1, paragraph 1, the

Convention does not solely refer to "race" and has a meaning and application which complement the other prohibited grounds of discrimination,

Strongly reaffirming that discrimination based on "descent" includes discrimination against members of communities based on forms of social stratification such as caste and analogous systems of inherited status which nullify or impair their equal enjoyment of human rights.

General recommendation XXIX on article 1, paragraph 1, of the Convention (Descent), online: United Nations

$<$ http://tbinternet.ohchr.org/layouts/treatybodyexternal/Download.aspx?symbolno $=I N T \% 2 f C E R D \% 2 f G E C \% 2 f 7501 \& L$ ang=en>.

35 For the related information see, Caste Discrimination and Human Rights (1 July 2015), online: International Dalit Solidarity Network_<http://idsn.org/wp-content/uploads/2015/07/IDSN-and-PDSN-alternative-report-on-ScheduledCaste-Children-in-Pakistan-July-2015-CRC-Pakistan.pdf>.

36 A/HRC/11/CRP.3

37 For a critical view on this see, Kenneth Anderson, "The Ottawa Convention Banning Landmines, the Role of International Non-governmental Organizations and the Idea of International Civil Society" (2000) 11 Eur J Intl L 91. For a detailed analysis on the impact of social movements on the international law making see, Balakrishnan Rajagopal, International Law from Below: Development, Social Movements and Third World Resistance (New York: Cambridge University Press, 2003). 
particularly TWAIL scholarship is left untouched by these anti caste movements, in the context of the caste-race debate in India.

\section{INDIAN INTERNATIONAL LAWYERS AND THE QUESTION OF CASTE DISCRIMINATION}

The apparent reality of the caste system and its attendant reality of a hierarchical labour division led to the exclusion of lower castes from certain tasks designated as intellectual. This centuries-old practice led to the absence of lower caste people in academia in the contemporary world and it is evident invariably across disciplines. The field of law is not an exception to this phenomenon. Studies have shown how people belonging to lower castes are not adequately represented in the Indian higher judiciary and the challenges they face in law schools. ${ }^{38}$ What needs to be emphasized for the purpose of the present article is that the lack of representation of people belonging to lower castes in academia in general is also true with the discipline of international law. Furthermore, the absence of people belonging to lower castes in the knowledge production in the field of international law also seems to be one of the important reasons for the absence of histories and lived experiences which otherwise should have become issues of analysis in international law, in general and in TWAIL scholarship, in particular.

\section{A. Social Composition of Indian International Law Scholars}

So far, there has not been any empirical data on the socio-economic background of Indian international lawyers in general. However, a conclusion can be drawn from the absence of these groups in academia in general and also based on studies on the social composition of the higher judiciary in India and some examples from law schools. As the international law discipline is in a way an overly specialized field of study and not many universities in India have well developed international law departments, it can be argued, based on other relevant data, that participation of people belonging to lower castes in international law scholarship in India or occupying international law related positions on behalf of India is at best nominal, if not nil. This itself should be the cause of concern for any society which claims to be based on the notion of equality and rule of law. The social background of those who occupied positions at the international level, mainly at places like international courts and tribunals and at the International Law Commission suggests that there is an absence of people belonging to lower castes in international law. A cursory look at the post-independence India's representation at the international level in the field of international law reveals the absence of lower castes in the field of international law from India. So far the International Court of Justice [ICJ] had four judges and four ad hoc judges from India. Of the seven (seven because Nagendra Singh held both positions), six are Hindus and one Muslim. All the six Hindus come from upper castes. ${ }^{39}$ Similarly, so far, India has sent six

38 See, George H. Gadbois Jr, Judges of the Supreme Court of India: 1950-1989 (New Delhi: Oxford University Press, 2011); Alok Prasanna Kumar, "Absence of Diversity in the Higher Judiciary" (2016) 8 Economic and Political Weekly 10. For the challenges lower caste students face in law school recruitments in India see, Shamnad Basheer et al "The Making of Legal Elites and the IDIA of Justice" (2014) HLS Program on the Legal Profession Research Paper No. 201418, online: SSRN <http://papers.ssrn.com/sol3/papers.cfm?abstract_id=2433036>.

39 Judges of the ICJ from India are: Sir Benegal N Rao (1952-53), Nagendra Singh (1973-1988), Raghunandan Swarup Pathak (1989-1991) and Dalveer Bhandari (2012-). Ad hoc judges from India are: Mohamed Ali Currim Chagla, 
persons to be members of the International Law Commission [ILC]. Of the six, five are from upper castes and only one is from a lower caste. ${ }^{40}$ Legal scholarship in India, in general, and international law scholarship, in particular, does not seem to take cognizance of this absence. One of the fundamental premises on which international human rights law is based is anti-discrimination. Any engagement with the principle of anti-discrimination cannot afford to lose sight of the absence of certain sections of people belonging to certain social categories; in the present case, lower castes. What needs to be underlined is that the absence of certain groups itself is a reflection of social reality which cannot be ignored either in policy-making or when engaging in a critical analysis like TWAIL does. The scholarship from India that broadly engaged with third world perspectives does not seem to grapple with the issue of participation of different social groups in the international law scholarship and in occupying international law positions on behalf of India. While the absence of adequate representation continues to be a serious concern, one also has to explore the implications of this absence in relation to the analysis of international law. A further question is, if there are any such implications, has the international law scholarship from India been able to capture them?

In the last few decades, there has been a social science research inquiry in India from the perspective of caste inequalities. This inquiry was not just confined to the absence of the lower castes in the positions of power in economic, political and social spheres. The inquiry significantly includes investigating the absence of histories, political discourses, social and cultural practices of the people of lower castes in the mainstream and dominant narratives. What needs to be examined is whether this exclusion of lived experiences of the lower caste peoples is also endemic to the studies in law, particularly international law? Historically international law's confinement to interstate relations, left these matters internal to a State to domestic regulation and accordingly issues like caste discrimination were kept out of the discourses of international law. However, with the emergence of international human rights law, issues that were traditionally considered as internal to a State were brought onto the agenda of international law. This development did not however fully change the image of international law as an instrument to regulate interstate relations. This image continues to dominate the discourses of it in India. The dominant views on international law in India are confined to understanding it in its traditional sense of keeping domestic affairs away from international law regulation.

Certain strands of TWAIL scholarship have broken this tradition and argued for making people central to the debate rather than States. It not only focused on looking at the impact of international law on peoples, but peoples' movements in India have also become subjects of study for TWAIL scholars. ${ }^{41}$ However, TWAIL's analyses do not significantly reflect the issues of concern to the lower caste's lived experiences and their possible emancipation through international legal frameworks and institutional mechanisms. Caste discrimination is a social phenomenon very much linked to Hinduism in the Indian context. Its prevalence is thus evident in India but similar practices exist in other South Asian countries

Nagendra Singh, B.P. Jeevan Reddy and Pemmaraju Sreenivasa Rao. As the caste of the persons is not mentioned in all the cases of government appointments, it is not possible to know the caste background of people through official sources. Hence this information is gathered through informal and personal sources. This is applicable to note 40 also.

40 The ILC members from India are: Sir Benegal N Rau(1949-1951), Radhabinod Pal(1952-66), Nagendra Singh (19671972), SP Jagota (1977-1986), PemmaRaju Sreenivasa Rao (1987-2006) and Narinder Singh (2007-2016).

41 See Antony Anghie and BS Chimni, "Third World Approaches to International Law and Individual Responsibility in Internal Conflicts" (2003) 2 Chinese J Intl L 77; and Rajagopal, supra note 37. 
also. Despite its gravity and widespread practice, it has not received adequate attention from the international community. It has also not attracted adequate attention in the debates on international law including international human rights law.

\section{B. Indian International Law Scholarship on the Question of Caste}

When the debate on caste and race was taking place in the context of the Durban conference there were many scholars who expressed their views on the issue. Most of these scholars were from the disciplines of sociology, political science, economics, as well as journalists and activists. There were a few from the legal domain but they were essentially from the domestic law field. Most of these debates were taking place in the print media and journals. A cursory survey of the literature reveals that Indian international lawyers did not seriously engage with this question during the debates. ${ }^{42}$ There was almost an absence of voices of international lawyers, even when the debate was able to attract views from cross section of the academia and Indian society. There was not much engagement with the issue at the international level as well. ${ }^{43}$ What is significant is that those who are broadly identified with third world approaches in international law scholarship were not part of this debate. ${ }^{44}$ As discussed in the previous section, the caste-race debate essentially took place in relation to international law discourses, however, it did not attract much the scholarly attention from TWAIL scholars.

\section{Indian International Law Scholarship on Anti-Colonial and Post-Colonial Protagonists}

Indian international law prominently engaged with the history of international law, particularly in reference to India. Some prominent TWAIL writings are historically rooted to establish third world assertions. $^{45}$ As a continuity to an historical past a few writings have also dealt with anti-colonial struggles in India and post-colonial developments. Most importantly, prominent Indian TWAIL scholars focused on some of the individuals who notably figure in anti-colonial and post-colonial Indian social and political reality. The two prominent personalities that mostly attract the attention are Gandhi and Nehru. Gandhi's engagement is not confined to the anti-colonial movement alone. He was engaging with

42 A book compiling important writings on the issue by Indian scholars does not contain a piece from any international lawyer either from India or from outside India. See Thorat \& Umakant, supra note 25. This book is a compilation of views expressed when the discussion around Durban conference was taking place.

43 However, there are a few writings on some aspects of the caste issue: Laura Dudley Jenkins, "Race, Caste and Justice: Social Science Categories and Antidiscrimination Policies in India and the United States" (2004), 36 Conn L Rev 747; Clifford Bob “'Dalit Rights are Human Rights': Caste Discrimination, International Activism, and the Construction of a New Human Rights Issue" (2007) 29 Hum Rts Q 167; Jeremy Sarkin \& Mark Koenig, "Ending Caste Discrimination in India: Human Rights and the Responsibility to Protect (R2p) Individuals and Groups from Discrimination at the Domestic and International Levels" (2010) 41 Geo Wash Intl L Rev 541; Scott Grinsell "Caste and the Problem of Social Reform in Indian Equality Law” (2010) 35 Yale J Intl L 198; Annapurna Waughray "Caste Discrimination and Minority Rights: The Case of India's Dalits" (2010) 17 Intl J Minority Group Rights 327. David Keane, Caste-based Discrimination in International Human Rights Law (Aldershot: Ashgate, 2007).

44 A few writings deal with the issue but they do not comprehensively address it in the context of international law; Upendra Baxi "Emancipation as Justice: Babasaheb Ambedkar's Legacy and Vision" in Upendra Baxi \& Bhikhu Parekh, eds, Crisis and Change in Contemporary India (New Delhi: Sage, 1995); BS Chimni "Alternative Visions of Just World Order: Six Tales from India” (2005) 46 Harv Intl LJ 389.

45 RP Anand's writings reflect this aspect prominently. 
issues of polity, economy and society. While Nehru was equally in the forefront of the anti-colonial struggle, his contribution is contextualized more in relation to post-Independence reconstruction of India and his role in forming newly Independent India's foreign policy. Two prominent TWAIL scholars have written on these two important figures from India. R.P. Anand dealt with the role and contribution of Nehru in shaping India's foreign policy and his importance in the context of international law. ${ }^{46}$ B.S. Chimni has written on Gandhi's anti-imperialist ideas and his alternative political and economic worldview. ${ }^{47}$ These scholarly contributions are of importance for international law discussions involving India. They are of equal significance for the TWAIL movement as these two statesmen's ideas, along with other anti-colonial political personalities in Asia and Africa, have influenced the ideas of third world assertion in the field of international law. In the context of India, along with these two prominent figures there are also others who deserve serious scholarly attention. Particularly in relation to the field of law one prominent figure who cannot be ignored is B.R. Ambedkar (1891-1956). Ambedkar was from the untouchable Mahar community. He got the opportunity to study abroad, which was rare for persons from the 'untouchable' communities during his time. After returning from his studies, he mobilized Dalits and led the anti-caste struggles. After the independence of India, he was elected as the chairman of the drafting committee of the constitution of India. He was also the first law minister of India. Ambedkar mobilized lower caste people against caste discrimination and often confronted with the dominant anti-colonial discourses, including of Gandhi. As chairman of the drafting committee he played a significant role in the making of the Indian Constitution. ${ }^{48}$ However, so far, none of the writings of international lawyers from India refer to Ambedkar in a prominent way.

Absence of scholarship on persons like Ambedkar may be considered as a mere failure to adequately capture the contribution of prominent persons. However, that explanation loses sight of the conceptual standpoints from which these individuals looked at anti-colonialism, nationalism and anti-imperialism, the subject matters of TWAIL scholarship. Broadly, Gandhi and Nehru, inter alia, may be categorized as nationalists with anti-colonial agenda. However, Ambedkar did not share similar ideas. He was critical of these ideas of Gandhi and other prominent leaders. TWAIL scholarship, essentially focusing on anticolonial struggles as a conceptually uniting factor, is inclined towards analyzing the contributions of personalities like Gandhi and Nehru, in the process ignoring people like Ambedkar who had fundamental differences with them.

This takes us to the larger question of whether the absence of people belonging to lower castes is merely a matter of opportunity and time or are there social practices which reinforce the caste hierarchy and exclude people from lower castes? Caste discrimination like any other social inequality requires intellectual and political engagement towards eliminating it. Failure to engage with the issue only reinforces the discrimination and inequality. Thus the lack of critique internal to the discipline of international law can be considered as an important reason for the absence of lower caste people in the

46 RP Anand, "Jawaharlal Nehru and International Law" (2002) 42 Indian J Intl L 5.

47 BS Chimni, "The Self, Modern Civilization, and International Law: Learning from Mohandas Karamchand Gandhi's Hind Swaraj or Indian Home Rule" (2012) 23 Eur J Intl L 1159. Interestingly, as Arundhati Roy rightly points out, Hind Swaraj, which is considered as an important text by Gandhi does not make any reference to caste. Roy, supra note 15 at 84.

48 See online: $<$ http://ambedkarfoundation.nic.in/html/profile-Drambedkar.pdf $>$. 
international law scholarship and in institutions, and also a reason for the failure to take cognizance of the lived experiences of the lower caste people as issues of importance to international law.

This further leads us to the question of whether the conceptual premise which TWAIL scholarship predominantly relies upon is itself a hindrance to understanding the question of caste? As pointed out earlier, one of the prominent conceptual premises of TWAIL scholarship is a north/south dichotomy and linking the same to anti-colonialism and looking at the post-colonial reality from the perspective of an anti-colonial framework. But, for the lower caste people, the fundamental issue has been where they are placed in the anti-colonial and post-colonial discourses. In this context, differences of opinion between Gandhi and Ambedkar in the background of anti-colonial struggle become important.

\section{IS TWAIL INHERENTLY INCAPABLE OF ADDRESSING CASTE DISCRIMINATION?}

A survey of TWAIL scholarship in general and, particularly, from the south Asian subcontinent reveals that caste discrimination has not been adequately addressed in the context of international law. Reasons for this can be partially explained from the absence of scholars with lived experiences of lower castes among the international lawyers coming from the subcontinent. In other words, there is an absence of the scholars who are organically linked ${ }^{49}$ to the everyday reality of lower castes whose plight reflects the manifold forms of violation in the language of rights. The other important explanation can be the limitations of the conceptual premise on which TWAIL scholarship is broadly based. Arguably, the TWAIL conceptual premise limits itself from addressing the question of caste. As pointed out earlier, the agenda of TWAIL as articulated in its vision statement critiques the privileging of the west over the rest and implicitly links it up with colonialism and resultant post-colonial realities in third world countries. ${ }^{50}$ This broad conceptual framework invariably excludes other forms of hierarchies and discrimination which do not fit into it. Caste discrimination in its origins and nature is predominantly specific to the global south and it predates colonialism. TWAIL group's commitment to understanding international law from the standpoint of the north/south or east/west binary and the colonial past implicitly attributes all forms of hierarchy and oppression in the third world to the encounter with the west or relegates other forms of hierarchy and oppression, which are not linked to the western domination, to a secondary position. Either way caste discrimination slides out of the TWAIL analysis. Historically the caste question has an uneasy relation with the anticolonial discourses and movements in the subcontinent. The anti-caste movements led by B.R. Ambedkar had a skeptical relationship with the anti-colonial movement as articulated and led by Gandhi and others. Ambedkar wanted the caste question to be dealt with while waging the anticolonial struggle. Differences between Ambedkar and Gandhi on issues like the caste system and Communal Award were a clear reflection of their different perceptions on the anti-colonial struggle, caste questions and the future of an independent India. Thus, the absence of TWAIL's engagement with caste discrimination in the context of international law may not be an aberration but has its source in TWAIL's loosely defined objectives of its critical scholarship.

\footnotetext{
49 Gramsci's classification of intellectuals into organic and traditional may be helpful in understanding this phenomenon. See, Antonio Gramsci, Selections from the Prison Notebooks (New York: International Publishers, 1992).

50 Mickelson, supra note 3.
} 
This conceptual constraint can be negotiated by deploying a critical Dalit legal perspective of bringing the caste question into the realm of TWAIL critical scholarship. This can be made possible by delinking the north/south or east/west binary from colonial encounter and placing it in the larger context of economic, political and social struggles. There is a possibility of a TWAIL conceptual framework accommodating caste discrimination in terms of the privileged global north dominating the global south. The inadequate engagement with the caste discrimination in the international human rights law corpus can be questioned within the TWAIL conceptual framework of privileging global north over global south. The existing international human rights corpus is essentially based on the western liberal tradition of individual human rights and, arguably, existing human rights law predominantly addresses those forms of discrimination which are of concern to the global north. For this reason, since its inception, the human rights framework is questioned for being individualistic and western-centric. Therefore, it can arguably be asserted that the absence of a comprehensive engagement with caste discrimination in substantive international human rights law corpus is the result of privileging those forms of discrimination which are specific to the north while ignoring others like caste.

\section{CONCLUSION}

TWAIL as a methodological framework so far has not been able to adequately reflect, with a few exceptions, on issues like caste discrimination in the context of international law. One of the reasons for this is the lack of an internal critique of international law scholarship particularly within India. In terms of its gravity and impact on the number of people, caste discrimination deserves international law attention. This is not to argue that international normative and institutional mechanisms alone are better suited to address the problem. However, as seen in the case of other forms of discrimination and human rights violations, it is of significant value in building solidarity with similarly placed peoples and bringing pressure on the relevant State machinery to address the issue.

There is a paucity of debate on the issue of caste discrimination at the international level. The critical international law scholarship from India, like TWAIL, suffers from this paucity as well. Any attempt to analyze the situation leads one to explore the probable reasons for this scenario. One reason could be the mainstream and liberal view of the field of law which considers it as neutral and impartial and insulates it from the political and social considerations. This view of the rule of law assumes that law operates without any consideration of the material, social and cultural reality of individuals and groups. This understating largely stems from the statist and mainstream view of international law.

The other reason could be the privileged social background of legal academics, and particularly international law scholars, whose lived experiences immunize them from capturing and analyzing the social phenomenon of caste as part of their world of ideas. This is not to argue the impossibility of overcoming the subjective social and material constraints of these scholars. It is to underline that it did not effectively happen in this case. A similar situation is evinced in other contexts where similar forms of discrimination exist. In the context of racial discrimination in the global north, mainly in the United States, the overt and insidious operation of race resulting in the exclusion of blacks from the legal field is recognized. As a response to such a situation black scholars, articulated an anti-discrimination discourse through a critical engagement which emerged as critical race theory (CRT) used mainly in U.S. academia. The TWAIL scholarship that is specifically emerging from the South Asian subcontinent 
has an opportunity to engage with the question of caste discrimination in the context of international law. However, as pointed out earlier, TWAIL's primary agenda is the exclusion of the global south from the scholarship and from the narratives of mainstream international law. Caste discrimination, a phenomenon primarily of the global south with the global southern postcolonial State playing the role of either perpetrator or mute spectator, might find itself in a position which may not be fully contradictory to the TWAIL programme but, at the same time, may not be in consonance with its primary agenda. Therefore, there is a need for the TWAIL scholarship to address the caste question by creatively applying its progressive narrative to the context. It is argued that there should be a conversation and collaboration between critical race theory and TWAIL. ${ }^{51}$ Similarly, there is a need to develop critical Dalit legal studies in the South Asian context as an extension of TWAIL scholarship whose agenda should be to critically evaluate the field of law from a caste perspective both at the domestic and international levels.

51 Makau Mutua, "Critical Race Theory and International Law: The View of an Insider-Outsider" (2000) 45 Vill L Rev 852. 